\title{
PERINGKAT DESTINASI DAN STRATEGI PENGEMBANGAN DAYA TARIK WISATA PANTAI DI KABUPATEN BANTUL YOGYAKARTA
}

\author{
Atun Yulianto \\ NIDN : 0505077401 \\ Akademi Pariwisata BSI Yogyakarta \\ E-mail: atun.aty@bsi.ac.id
}

\begin{abstract}
The rapid development of tourism in Daerah Istimewa Yogyakarta becomes a trigger for Indonesian people to choose Yogyakarta as a destination worth visiting with a variety of potential tourism.Bantul Regency is one of the areas in the Special Region of Yogyakarta which borders directly with the Indian Ocean so that many have coastal tourist-oriented tourist destinations. Of the many beaches in the district of Bantul, each has its own beauty and characteristic respectively. Potential Attractiveness Coastal tourism in the district of Bantul in the book Tourism Statistics DIY 2016 include Parangtritis Beach, Samas Beach, Pandansimo Beach, Cave Beach Cave and Kuwaru Beach. The approach developed by the government through the Ministry of Tourism to improve the competitiveness of coastal tourism (marine) is to integrate the first dimension of infrastructure, accessibility, connectivity, activity, facilities, hospitality and market preferences. And the second is to increase synergy between local governments, business actors, and local communities (DITJEN Kerjasama ASEAN, 2015:19). However, not all the development of tourist areas can be applied in the coastal areas of Bantul regency that has a high sea wave and the proximity of the sea trough with coastal areas so it is very risky to the safety of tourists. Various complaints submitted by visitors, among others; there are still services that are not standard (expensive), there is a slum beach section, sometimes neglected discipline, clutter of land governance, multiple levies, and beach raids by various business activities make the potential of visits to coastal tourism in Yogyakarta reduced (Prasetya et al , 2015: 135). The purpose of this research is to know the most visited tourism potential and alternative tourism development strategy based on SWOT analysis. The research method used is descriptive qualitative approach. The results showed that Parangtritis Beach became the most favorite beach with the number of visitors which increased from year to year. One of the SWOT analysis of tourism development strategy in Bantul regency tourism object is by creating a special place, which is built in such a way with the background of natural panorama of the beach, to exploit the passion of swafoto visitors (selfie) as part of modern marketing through social media tourists.
\end{abstract}

Keywords: Attraction, Beach, Strategy

\section{PENDAHULUAN}

Pembangunan pariwisata Daerah Istimewa Yogyakarta direncanakan berdasar-kan PERDA DIY Nomor 1 tahun 2012 tentang rencana induk pembangunan kepariwisataan DIY. Dalam visinya, pembangunan kepariwisataan daerah dimaksudkan untuk terwujudnya Yogyakarta sebagai Destinasi Pariwisata berbasis budaya terkemuka di Asia 
Tenggara, berkelas dunia, berdaya saing, berkelanjutan, mampu mendorong pembangunan daerah untuk kesejahteraan masyarakat. Sedangkan salah satu misinya adalah mengembangkan tujuan Wisata yang aman, nyaman, menarik, mudah dicapai, dan berwawasan lingkungan sehingga mampu meningkatkan kesejah-teraan masyarakat;

Ruang lingkup rencana induk pembangunan pariwisata DIY mencakup beberapa aspek diantaranya pembangunan destinasi pariwisata, pemasaran pariwisata, industri pariwisata dan kelembagaan pariwisata (PERDA DIY, 2012). Pelaksanaan rencana induk pembangunan periwisata DIY memerlukan kerja sama dari berbagi pihak mulai dari pemerintah, pelaku pariwisata, industri pariwisata, usaha pariwisata, pengelola destinasi wisata, MICE dan masyarakat. Pemerintah daerah berserta masyarakat pelaku wisata telah banyak mengembangkan destinasi wisata baru diberbagai wilayah di DIY. Namun yang paling penting dengan potensi wisata yang telah dimiliki DIY, sinergitas antar elemen terkait diperlukan untuk mendapatkan formula yang tepat dalam merumuskan pemasaran pariwisata yang efektif guna meningkatkan kunjungan wisatawan baik nusantara maupun mancanegara.

Kabupaten Bantul merupakan salah satu wilayah di Daerah Istimewa Yogyakarta yang berbatasan langsung degan samudera India sehingga banyak memiliki destinasi wisata berciri pesisir pantai. Dari sekian banyak pantai yang ada di kabupaten Bantul, masing-masing memiliki keindahan dan ciri khas sendirisendiri. Dari sudut tinggi gelombang dapat dikategorikan hampir semua sama, namun dari segi luas pesisir pantainya sangat berbeda-beda pantai yang satu dengan lainnya. Luas pantai dapat mempengaruhi ruang gerak pelaku wisata dalam menciptakan objek daya tarik wisata baik buatan maupun terbentuk karena alam.

Pesisir pantai di kabupaten Bantul memiliki garis pantai sepanjang $16,85 \mathrm{~km}$ (Budiantoro, 2017), meliputi wilayah kecamatan Srandakan, Sanden Dan Kretek. Dengan keindahan dan ciri khasnya masing-masing pantai di kabupaten Bantul banyak dikembangkan menjadi tempat wisata pesisir. Hal ini sejalan dengan visi poros maritim yakni menjadikan laut Indonesia sebagai pusat dinamika dan kegiatan ekonomi regional dan global melalui kerjasama di bidang infrastruktur laut, perkapalan, pelayaran, perikanan, dan pariwisata (DITJEN Kerja Sama ASEAN, 2015). Pengembangan pariwisata daerah pesisir kabupaten Bantul menghasilkan pantai-pantai yang menjadi unggulan dalam menghasilkan pendapatan daerah (PAD) diantaranya pantai Parangtritis. Selain itu terdapat beberapa objek wisata pantai lain yaitu Pantai Parangkusumo, Pantai Depok, Pantai Samas, Pantai Pandansimo, Pantai Goa Cemara, dan Pantai Kuwaru.

Pendekatan yang dikembangkan pemerintah melalui Kementerian Pariwisata dalam meningkatkan daya saing wisata pantai (bahari) yang pertama yaitu mengintegrasikan dimensi infrastruktur, aksesibilitas, konektivitas, aktivitas, fasilitas, hospitality dan preferensi pasar. Yang kedua adalah meningkatkan sinergi antara pemerintah daerah, pelaku bisnis, serta masyarakat lokal (DITJEN Kerjasama ASEAN, 2015:19). Sejalan dengan program pemerintah ini, pelaku wisata di Daerah Istimewa Yogyakarta tidak tinggal diam dengan mengembangkan beberapa program agar kunjungan wisatawan baik domestik 
maupun manca negara dapat ditingkatkan dari tahun ke tahun. Dikutip dari surat kabar Kedaulatan Rakyat Senin 8 Januari 2017, bahwa pelaku wisata bisnis perhotelan di Yogyakarta bekerja sama dengan Asosiasi Perjalanan Wisata Indonesia (ASITA) meyiapkan tiga program besar yaitu Jogja Heboh, Jogja Vaganza, dan Jogja International Travel Mart di tahun 2018 untuk mendongkrak jumlah kunjungan wisatawan ke D.I. Yogyakarta

Imbas dari program tersebut secara tidak langsung diharapkan dapat mempengaruhi jumlah kunjungan ke objek daerah tujuan wisata disemua wilayah DIY termasukke kabupaten Bantul Yogyakarta. Objek wisata unggulan yang berada di kabupaten Bantul adalah kawasan pesisir pantai yang menarik dan memiliki keindahan tersendiri sehinggamenjadi daya tarik bagi calon pengunjung untuk memutuskan agenda kunjungannya kekawasan wisata ini.Namun demikian dari sekian banyak kelebihan yang ada dikawasan pesisir pantai yang dijadikan sebagai objek daerah tujuan wisata terdapat beberapa masalah terkait dengan pengebangan tempat wisatanya. Beberapa hal dapat dikembangkan dikawasan pantai seperti olah raga memancing, layar, selam, keindahan patai, kuliner laut, kegiatan pesisir, akomodasi, dermaga kapal/ikan, penyewaan kapal, pembuatan kapal, lemacar air, selam, terumbu karang, pohon bakau, cemara dan lain-lain. Namun demikian tidak semua pengembangan kawasan wisata tersebut dapat terapkan di daerah pesisir pantai kabupaten Bantul yang memiliki tinggi gelombang laut yang tinggi dan dekatnya palung laut dengan daerah pesisir sehingga sangat beresiko pada keselamatan wisatawan. Berbagai keluhan yang disampaikan pengunjung antara lain; masih terdapat layanan yang tidak standar (mahal), terdapat bagian objek yang kumuh, tata tertib yang kadang terabaikan, kesemrawutan tata kelola lahan, pungutan ganda, dan penyerobotan pantai oleh berbagai aktivitas bisnis menjadikan potensi minat berkun-jungke objek wisata pantai di Yogyakarta berkurang (Prasetya dkk, 2015).

Atas dasar uraian latar belakang diatas, banyak peluang yang dapat menjadi dasar menentukan strategi pengembangan dan mengantisipasi ancaman yang ada. Tujuan penelitian dalam artikel ini adalah untuk mengetahui potensi wisata paling banyak dikunjungi dan alternatif strategi pengembangan objek wisata berdasarkan SWOT analisis di kawasan pesisir pantai di kabupaten Bantul.

\section{LITERATURE REVIEW \\ Pariwisata}

Keanekaragaman hayati dan sumber daya alam yang dimiliki negara Indonesia selain dijaga kelestariannya juga perlu dikelola dalam suatu pengelolaan yang terpadu dan terintegrasi, sehingga dapat memberikan manfaat baik secara ekonomi, sosial, dan budaya bagi bangsa dan negara ini. Pengelolaa daya tarik lingkungan alam dan budaya di destinasi pariwisata secara terpadu sangat dibutuhkan untuk mewujudkan program pemeritah dalam pembangunan destinasi pariwisata berkelanjutan.Definisi pariwisata dalam penjelasan Peraturan Menteri Pariwisata nomor 14 tahun 2016 disebutkan bahwa "Pariwisata adalah berbagai macam kegiatan wisata dan didukung berbagai fasilitas serta layanan yang disediakan oleh masyarakat, pengusaha, Pemerintah, dan Pemerintah Daerah. Sedangkan Wisata 
adalah kegiatan perjalanan yang dilakukan oleh seseorang atau sekelompok orang dengan mengunjungi tempat tertentu untuk tujuan rekreasi, pengembangan pribadi, atau mempelajari keunikan daya tarik wisata yang dikunjungi dalam jangka waktu sementara (Hasan, 2015). Dalam hal ini orang atau sekelompok orang yang melakukan perjalanan untuk tujuan wisata, seperti untuk berekreasi, berbisnis maupun untuk memenuhi kebutuhan-kebutuhan khusus yang lain disebut wisatawan (Sunaryo, 2013).

\section{Daya Tarik Wisata}

Daya tarik wisata adalah usaha yang kegiatannya mengelola daya tarik wisata alam, daya tarik wisata budaya, dan daya tarik wisata buatan manusia (Ismayanti, 2010). Sedangkan menurut Pendit (2003) dalam Utama (2016), daya tarik wisata adalah segala sesuatu yang menarik dan mempunyai nilai untuk dikunjungi dan dihat. Definisi lain dalam UU Republik Indonesia No.10 Tahun 2009, menyebutkan bahwa daya tarik wisata adalah segala sesuatu yang memiliki keunikan, keindahan, dan nilai yang beranekaragam berupa kekayaan alam, budaya dan buatan manusia yang menjadi sasaran atau tujuan kunjungan wisatawan. Hal ini juga sejalan dengan pendapat Marpang (2002) dalam Kete (2016), lebih lanjut menjelaskan bahwan objek dan daya tarik wisata adalah suatu bentuk dan/atau aktifitas serta fasilitas yang saling berhubungan dan menjadi magnet bagi wisatawan untuk melakukan kunjungan pada daerah destinasi. Berdasarkan beberapa definisi diatas maka dapat disimpulkan bahwa daya tarik wisata adalah segala sesuatu yang memiliki magnet (nilai) untuk dilihat dan dikunjungi karena keunikan dan keindahannya yang berupa wisata alam, budaya dan buatan manusia dengan segala aktifitas serta fasilitas yang mendukung kunjungan wisatawan pada daerah destinasi.

\section{METODE PENELITIAN}

Penelitian ini lebih menggambarkan secara riil keadaan sesungguhnya objek penelitian baik dari askpek fisiologis, dokumentasi maupun data jumlah kunjungan. Metode penelitian yang dikembangakan dalam penelitian ini menggunakan pendekatan diskriptif kualitatif. Data objek daya tarik wisata pantai paling populer di kabupaten Bantul diolah berdasarkan data statistik pariwisata DIY tahun 2016 dengan mengurutkan secara descending sehingga didapatkan data baris mulai dari jumlah pengunjung terbanyak. Strategi pengembangan daya tarik wisata dirumuskan menjadi matrik SWOT berdasarkan riset dari kelebihan, kekurangan, peluang dan ancaman objek wisata pantai yang ada di sepanjang pesisir kabupaten Bantul. Data riset diperoleh melalui observasi, dokumentasi, pustaka, dan media online melalui website Pemerintah maupun Swasta yang mengulas tentang hal terkait dengan penelitian.

\section{HASIL PENELITIAN DAN PEMBAHASAN}

Daerah Istimewa Yogyakarta yang terletak pada bagian selatan kota Yogyakarta dan berbatasan langsung dengan samudera Hindia salah satunya adalah Kabupaten Bantul. Kabupaten Bantul memiliki luas area $506,85 \mathrm{~km}^{2}$ meliputi 17 kecamatan dan memiliki 75 desa (kelurahan). Potensi wisata di kabupaten Bantul berdasarkan data Dinas Pariwisata DIY tahun 2015 dalam Yulianto (2017), terdiri dari 17 Objek daya tarik 
wisata, meliputi Pantai Parang Tritis, Pantai Samas, Gua Selarong, Gua Cerme, Makam Imogiri, Pantai Pandan Simo, Pantai Kuwaru, Pantai Gua Cemara, Hutan Pinus, Kabun Buah Mangunan, Museum Wayang Kelayon, Museum Tani Jawa Indonesia, Museum Tembi Rumah Budaya, Museum
Purbakala Pleret, Museum Gumuk Pasir, Museum Soeharto dan 36 Desa Wisata di Bantul.

Berdasarkan data kuantitatif jumlah pengunjung objek wisata di Kabupaten Bantul dari tahun 2011 sampai tahun 2016 ditampilkan dalam tabel berikut :

Tabel 1. Jumlah Pengunjung Objek Daya Tarik Wisata Kabupaten Bantul Yogyakarta

\begin{tabular}{|c|c|c|c|c|c|c|c|}
\hline \multirow{2}{*}{ No } & \multirow{2}{*}{ Objek Daya Tarik Wisata } & \multicolumn{6}{|c|}{ Tahun } \\
\hline & & 2011 & 2012 & 2013 & 2014 & 2015 & 2016 \\
\hline 1 & Pantai Parang Tritis & 2.072 .085 & 1.773 .179 & 1.574 .730 & 2.179 .000 & 1.999 .870 & 2.229 .125 \\
\hline 2 & Pantai Samas & 38.316 & 51.900 & 55.698 & 78.936 & 140.850 & 247.293 \\
\hline 3 & Gua Selarong & 27.801 & 27.974 & 28.274 & 37.425 & 39.925 & 36.818 \\
\hline 4 & Gua Cerme & 22.456 & 20.032 & 16.924 & 24.356 & 13.455 & 13.520 \\
\hline 5 & Makam Imogiri & 23.296 & 31.230 & 31.230 & 7.637 & 9.810 & 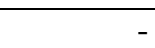 \\
\hline 6 & Pantai Pandansimo & 52.832 & 129.848 & 119.693 & 141.573 & 163.169 & 140.050 \\
\hline 7 & Pantai Kuwaru & 272.850 & 259.913 & 135.951 & 150.980 & 67.585 & 49.307 \\
\hline 8 & Pantai Gua Cemara & 11.667 & 11.667 & 75.374 & 88.909 & 95.260 & 84.687 \\
\hline 9 & Hutan Pinus & - & - & - & - & 143.338 & 582.261 \\
\hline 10 & Kebun Buah Mangunan & - & - & - & - & 230.004 & 396.759 \\
\hline 11 & Museum Wayang Kelayon & - & - & - & - & 2.914 & 3.669 \\
\hline 12 & $\begin{array}{lll}\text { Museum } & \text { Tani } & \text { Jawa } \\
\text { Indonesia } & & \end{array}$ & - & & - & - & 11.499 & 12.994 \\
\hline 13 & $\begin{array}{lll}\text { Museum } & \text { Tembi } & \text { Rumah } \\
\text { Budaya } & & \\
\end{array}$ & - & - & & - & 6.878 & 9.911 \\
\hline 14 & Museum Purbakala Pleret & - & - & - & - & 3.108 & 4.451 \\
\hline 15 & Museum Gumuk Pasir & - & - & - & - & 8.050 & 5.462 \\
\hline 16 & Museum Soeharto & - & - & - & - & 250.050 & 206.563 \\
\hline 17 & Desa Wisata (36 Desa) & - & - & - & - & 1.333 .434 & 1.112 .768 \\
\hline \multicolumn{2}{|c|}{ Jumlah } & 2.521 .303 & 2.305 .743 & 2.037.874 & 2.708.816 & 4.519 .199 & 5.148.633 \\
\hline
\end{tabular}

Sumber : Statistik Kepariwisataan DIY 2015/2016

Hasil olah data kuantitatif atas dasar jumlah pengunjung terbanyak selama enam tahun terakhir menempatkan pantai Parangtritis sebagai objek daerah tujuan wisata paling banyak dikunjungi wisatawan. Sedangkan dalam dua tahun terakhir menempatkan berbagai desa wisata yang tersebar di kabupaten Bantul sebagai daerah tujuan wisata urutan ke dua. Sementara dalam satu tahun terakhir hutan pinus berada pada posisi ke tiga sebagai daerah tujuan wisata yang paling banyak dikunjungi wisatawan.

Potensi daya tarik wisata pesisir pantai di kabupaten Bantul yang tercatat dalam buku statistik kepariwisataan DIY tahun 2016 meliputi pantai parangtritis, pantai samas, pantai pandansimo, pantai gua cemaradan pantai kuwaru. Namun demikian masih terdapat beberapa objek daya tarik wisata pantai lain yang belum tercatat karena dalam hal ini peruntukan pantai tersebut adalah sebagai tempat khusus seperti tempat pelelangan ikan, dermaga nelayan dan tempat konservasi hewan laut dilindungi.

Secara komprehensif pantai-pantai di sepanjang pesisir kabupaten Batul memiliki ciri dan keunikan dari panorama, pelayanan sampai dengan fasilitas yang hampir sama mulai pantai Parang Tritis, Samas, Pandansimo kuwaru dan Goa Cemara. 
Kelebihan, kekurangan, peluang dan ancaman daya tarik wisata dipesisir pantai kabupaten Bantul berdasarkan hasil riset adalah sebagai berikut :

1. Kelebihan

a. Memiliki panorama keindahan bentang alam dan laut dengan ombak besar yang menakjubkan

b. Pantai dengan pasirnya yang lembut dan menarik

c. Area pantai yang luas.

d. Objek wisata pendukung seperti : Parang Wedang, Parang Kusumo, Pengklik, tempat ziarah Pandan Sari dan Pandan Payung dll.

e. Didukung dengan budaya lokal masyarakatnya, seperti upacara kirab Tumuruning Maheso Suro dan Labuhan sedekah laut

f. Fasilitas pendukung kepariwisataan lengkap, antara lain : akomodasi hotel atau penginapan dengan harga yang bervariasi, toko souvenir dan oleholeh khas Bantul, warung makan, lahan parkir yang luas, kamar mandi, penyewaan dokar (kereta kuda), motor ATV, kuda wisata, paralayang. kolam renang anak/dewasa, tempat outbound dan camping, kereta api mini dan lain-lain

g. Fasilitas umum yang cukup lengkap, mulai dari terminal, tempat parkir, MCK, penginapan, SAR, jaringan listrik, mushola dan rumah makan dan lain-lain

h. Sudah banyak website dan media sosial yang memberitakan keindahan wisata pantai kabupaten Bantul

2. Kekurangan

a. Penataan taman yang masih perlu ditingaktakan sehingga lebih menarik

b. Fasilitas pariwisata cukup memadai namun kurang terawat c. Terjadinya abrasi dibagian pantai tertentu

d. Masih terdapat oknum penyedia sarana wisata yang belum memiliki ijin

e. Manajemen keamanan yang masih perlu ditingkatkan dari ancaman tindakan kriminal

f. Sampah yang masih perlu kedisiplinan pengelola dan pengunjung dalam menjaga kebersihan pantai

g. Strategi pemasaran cenderung konvensional dengan pengelola pariwisata yang sudah lama

h. Aksesbilitas sebagian pantai kurang memadai.

3. Peluang

a. Proyek pembangunan Jalur Jalan Lintas Selatan (JJLS) yang melewati tiga kabupaten di DIY (Gunungkidul, Bantul, dan Kulonprogo)

b. Konservasi penanaman pohon cemara udang Area di area pantai

c. Banyak even organiser tertarik menyelenggarakan event tahunan dikawasan pantai di kabupaten Bantul

d. Dilirik banyak produser sebagai lokasi pengabilan film/fotografi/video klip

e. Media sosial digunakan sebagain pengunjung update gambar dan video bagian pantai yang paling menarik.

f. Banyak investor yang ingin menanam-kan modal di kawasan wisata pantai selatan Bantul

g. Sumberdaya manusia melimpah dalam kelompok-kelompok seperti POKDARWIS

h. Stabilitas keamanan nasional yang baik dengan aparatur negara yang profesionalis.

4. Ancaman 
a. Persaingan objek wisata sejenis dari daerah lain

b. Investor masuk mengurangi lahan wisata sebagai tempat usaha/bisnis (pergesekan kepentingan)

c. Koordinasi yang lemah antara PEMDA dan pelaku pariwisata

d. Banyak kepentingan masuk yang tak terkontrol PEMDA maupun Dinas terkait, sehingga masih terdapat oknum penyedia fasilitas pariwisata yang belum berijin

e. Sampah laut f. Bencana alam gempa bumi dan tsunami

g. Strategi pemasaran modern yang diterapkan objek wisata luar daerah lainnya.

h. Sumberdaya manusia pariwisata yang trampil dan mumpuni masih kurang

Berdasarkan data sebelumnya maka disusun strategi rencana pengembanganagar objek daya tarik wisata pantai di kabupaten Bantul dapat terus bertahan dan banyak dikunjungi wisatawan dengan rencana strategi dalam bentuk metrik SWOT pada tabel berikut ini.

Tabel 2. Matrik SWOT

\begin{tabular}{|c|c|c|}
\hline $\begin{array}{l}\text { Intern: } \\
\text { Kekuatan } \\
\text { Ekternal }\end{array}$ & Kekuatan Internal & Kelemahan Internal \\
\hline $\begin{array}{l}\text { Pelu } \\
\text { Ekst }\end{array}$ & 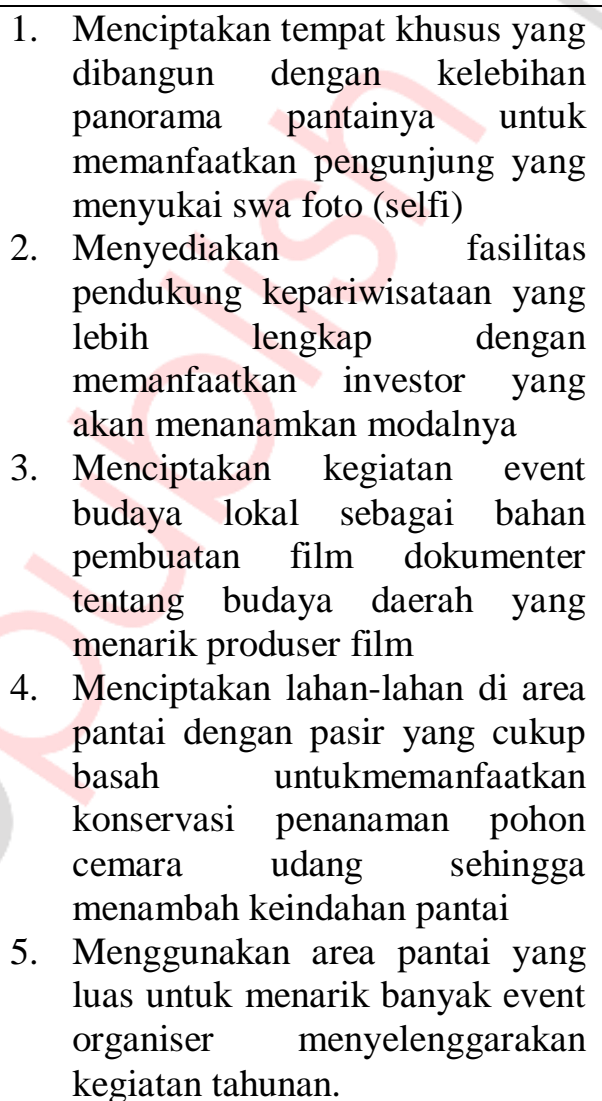 & $\begin{array}{l}\text { 1. Menciptakan tata taman yang } \\
\text { lebih baik dengan memanfaatkan } \\
\text { konservasi penenaman pohon } \\
\text { cemara udang sehingga pantai } \\
\text { lebih asri untuk menarik minat } \\
\text { kunjungan } \\
\text { 2. Menanggulangi abrasi pantai } \\
\text { dengan memanfaatkan } \\
\text { penanaman pohon cemara udang } \\
\text { 3. Meningkatkan kebersihan pantai } \\
\text { dengan memanfatkan sumber } \\
\text { daya manusia yang terlibat dalam } \\
\text { kepariwisataan } \\
\text { 4. Menciptakan aksesbilitas yang } \\
\text { lebih baik dengan memanfaatkan } \\
\text { adanya pembangunan jalur lintas } \\
\text { selatan DIY. a keamanan } \\
\text { 5. Menciptakan ban } \\
\text { wisatawan yang lebih baik } \\
\text { dengan memanfatkan } \\
\text { profesionalisme aparat keamanan }\end{array}$ \\
\hline $\begin{array}{l}\text { Ancaman } \\
\text { Ekternal }\end{array}$ & $\begin{array}{l}\text { Menciptakan pantai yang lebih } \\
\text { menarik dengan penataan taman } \\
\text { yang baik untuk menghadapi }\end{array}$ & \begin{tabular}{|lr} 
1. & Menciptakan penataan taman \\
pantai yang lebih baik sehingga \\
meningkatkan daya saing
\end{tabular} \\
\hline
\end{tabular}




\begin{tabular}{|c|c|c|}
\hline $\begin{array}{l}\text { Kekuatan } \\
\text { Internal } \\
\text { Kekuatan } \\
\text { Ekternal }\end{array}$ & Kekuatan Internal & Kelemahan Internal \\
\hline & 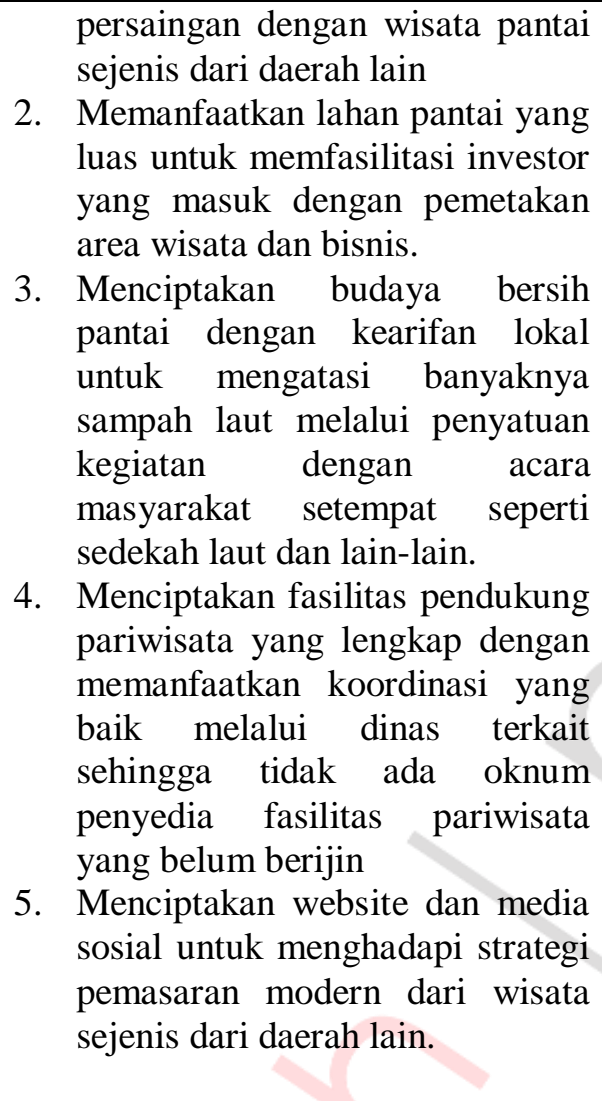 & 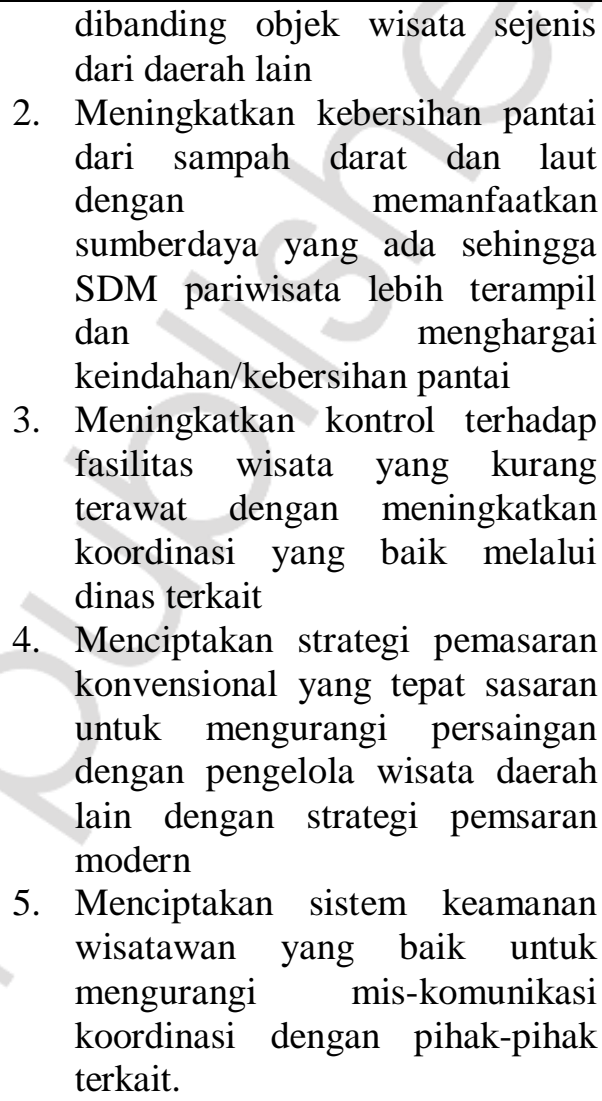 \\
\hline
\end{tabular}

Pembentuk komponen sistem kepariwisataan objek daya tarik wisata pantai di wilayah kabupaten Bantul diperoleh informasi hasil riset sebagai berikut :

a. Atraksi (daya tarik wisataalam, budaya, dan minat khusus)

Hasil observasi langsung menunjukkan bahwa daya tarik wisata pantai di pesisir kabupaten Bantul memiliki pesona yang menarik karena keunikan-nya berupa ombak laut yang besar, keberadaan nelayan bersandar, konservasi cemara udang sebagai peneduh dan penghalau kuatnya angin, atraksi budaya masyarakat lokal seperti sedekah laut, kirab budaya maheso suro, labuhan, kuda lumping, live musik campursari, dan pentasi seni tradisional maupun modern dari masyarakat sekitar.

b. Amenitas (akomodasi)

Pariwisata diera modern ini tidak dapat dianggap lengkap tanpa adanya sarana penungjang tempat menginap wisatawan. Fasilitas menginap (akomodasi) wisatawan dikawasan wisata pantai kabupaten Bantul sudah terpenuhi unsurnya. Banyak berdiri wisma, penginapan dan sekelas hotel melati tersebar sepanjang utara pantai Bantul dangan harga bervariasi dapat dimanfaatkan pengunjung untuk sekedar bermalam. Namun terkadang wisatawan terusik dengan kesan dari akomodasi yang berada disepanjang pantai atau tempat wisata pada umumnya adalah image negatif yang 
sejak dulu ada yaitu sebagai sarana prostitusi. Hanya dibutuhkan sedikit ketelitian karena tidak semua hotel, penginapan, wisma dan homestay yang ada disekitar pantai di kabupaten Bantul memiliki citra yang negatif, sehingga wisatawan hanya membu-tuhkan detail informasi baik secara online maupun offline dengan datang langsung. Keadaan ini dapat disiasasi wisatawan dengan memilih hotel, resort atau penginapan yang berada ditengah kota Bantul atau Yogyakarta sebagai tempat menginap. Homestay yang berada dikawasan desa wisata sekitar kabupaten Bantul juga menjadi alternatif menginap yang nyaman bagi wisatawan.

c. Aksesbilitas (transportasi)

Sebagian objek wisata yang sudah cukup lama seperti pantai Parangtritis membuat akses menuju lokasi wisata sangat mudah dicari baik melalui jalan Bantul, Parang Tritis, Imogiri maupun jalur lain yang dekat dengan objek wisata pantai di kabupaten Bantul. Dengan adanya proyek pembangunan jalur lintas selatan yang menghu-bungkan kabupaten Kulon Progo, Bantul dan Gunung Kidul semakin memudahkan lagi bagi wisatawan untuk menemukan jalan menuju lokasi wisata. Pada akhirnya sepanjang pantai di kabupaten Bantul dijadikan sebagai jalur wisata pantai terpadu. Antara pantai satu dengan lainnya dapat saling mendukung kedatangan wisatawan dengan kelebihan dan kharakteristik-nya masing-masing.

d. Infrastruktur pendukung

Kebutuhan infrastruktur pendukung yang berwujud pembangunan baik jalan, waduk, tanggul, perlistrikan, telekomunikasi, pelabuhan, saluran air besih, tempat ibadah, sistem keamanan dan lainnya yang mendukung kelancaran fungsi ekonomi kepariwi-sataan di pesisir pantai kabupaten Bantul baik sektor publik maupun privat telah disediakan oleh pemerintah daerah dan elemenelemen terkait dengan kompensasi sesuai aturan yang berlaku. Infrastruktur ini digunakan untuk mendukung fungsi sarana dan prasarana wisata pantai di Bantul baik berupa sebuah sistem yang mengatur arus aktifitas barang/jasa maupun bangunana fisik yang berada diatas dan dibawah permukaan tanah yang difungsikan sebagai pendukung kegiatan kepariwisataan.

e. Fasilitas pendukung lainnya

Fasilitas lain yang menunjang kebutuhan wisatawan di sepanjang pantai kabupaten Bantul adalah adanya berbagai macam jenis pedagang souvenir, rumah makan, penyewaan ATV, kereta kuda, kolam renang buatan, tempat outbond dan panggung hiburan menjadi fasilitas penunjang yang dapat memberikan pengalaman lain bagi pengunjung dalam berwisata.

f. Kelembagaan (sumberdaya manusia pariwisata)

Kelompok masyarakat sadar wisata (POKDARWIS) menjadi elemen penting dalam pengelolaan objek wisata yang bermunculan disepanjang pesisir pantai kabupaten Bantul. Kelembagaan masyarakat dibentuk dengan program kerja yang berkesinambungan sehingga objek wisata yang dikelola dapat tetap eksis 
sampai sekarang ini. Bekerjasama dengan pemerintah daerah dan dinas pariwisata terkait memberikan pelatihan dan penyuluhan untuk memperkuat kelembagaan dan profesionalisme SDM kepariwisataan (POKDARWIS), sehingga mampu bekerja serta menciptakan berbagai event kegiatan yang mendorong minat kunjung wisatawan ke objek wisata yang dikelola. Penguatan kelembagaan SDM pengelola wisata oleh dinas terkait dengan pendekatan dan komunikasi terus menerus kepada masyarakat, sebelum mengarah pada penataan maupun pembangunan fasilitas dan sarana prasarana pendukung wisata.

\section{KESIMPULAN DAN REKOMENDASI} Kesimpulan

Strategi pengembangan objek wisata dibutuhkan untuk menyusun perencanaan yang dapat meningkatkan baik kunjungan, fasilitas maupun keberlangsungan hidup object wisata itu sendiri. Atas dasar uraian pembahasan maka penulis memperoleh jawaban atas tujuan penelitian ini adalah sebagai berikut :

1. Peringkat destinasi pantai paling populer di kabupaten Bantul ditempati Pantai Parangtritis dari beberapa pantai lain berdasarkan jumlah pengunjung-nya. Selain karena pantai yang sejak lama ada, pantai ini juga sudah banyak dikenal baik wisatawan mancanegara maupun domestik dan seperti menjadi sebuah keharusan berkunjung ke Parangtritis bagi wisatawan luar daerah yang datang ke Yogyakarta.

2. Strategi pengembangan prioritas dari hasil analisis SWOT, yaitu : a. Menciptakan lebih banyak bangunan yang unik dan menarik dengan latar belakang panorama pantainya untuk memanfaatkan kegemaran pengunjung berswa foto (selfi) sebagai bagian dari pemasaran modern melalui sosial media wisatawan itu sendiri.

b. Menciptakan tata taman yang lebih baik dengan memanfaatkan adanya konservasi penanaman pohon cemara udang untuk menghasilkan pantai asri dan bersih sehingga menarik minat lebih banyak pengunjung.

c. Menciptakan website dan media sosial khusus untuk sejumlah pantai di kabupaten Bantul Yogyakarta dalam menghadapi strategi pemasaran modern (online) dari objek wisata sejenis dari daerah lain.

\section{Rekomendasi}

Kelompok masyarakat pengelola objek wisata pantai (POKDARWIS) dan pelaku wisata lainnya dapat melakukan studi banding ke objek wisata lain yang telah menerapkan strategi mengembangkan wisata modern melalui penciptaan sarana unik dan menarik menggali kegemaran individu sekarang yang sangat gemar update status atas keberadaannya disuatu lokasi wisata melalui media sosial. Tujuannya adalah untuk mengadopsi bagian strategi pengembangan objek wisata lain yang membuat sebuah objek wisata banyak dikunjungi wisatawan.

\section{REFERENSI}

Budiantoro, Agung. 2017. Zonasi Pantai Pendaratan Penyu di Sepanjang Pantai Bantul. Jurnal Riset Daerah.Edisi Khusus Tahun 2017. 
Kerjasama BAPPEDA Kabupaten

Bantul Dan UAD

DITJEN Kerja Sama ASEAN. 2015.

Buletin Masyarakat ASEAN :

Paradigma Baru Pariwisata

Indonesia. Edisi 7 / maret 2015.

Hasan, Ali. 2015. Tourism Marketing. Yogyakarta: Center for Academic Publishing Service.

Ismayanti. 2010. Pengantar Pariwisata. Jakarta : Gramedia Widiasarana Indonesia (GRASINDO)

Kete, Surya Cipta Ramadhan. 2016. Pengelolaan Ekowisata Berbasis Goa : Wisata alam Goa Pindul. Yogyakarta : Deepublish

Peraturan Menteri Pariwisata Republik Indonesai Nomor 14 Tahun 2016. Pedoman Destinasi Pariwisata Berkelanjutan

Prasetya, Teguh Budi, Endang Susilowati, Bambang Sugeng. 2015. Evaluasi Kinerja Pengelolaan Obyek Wisata Pantai Di DIY. Jurnal Maksipreneur, Vol.V, No. 1, Desember 2015

Sunaryo, Bambang. 2013. Kebijakan Pembangunan Destinasi Pariwisata (Konsep Dan Aplikasinya Di Indonesia). Yogyakarta ; Gava Media

Utama, I Gusti Ngurah Rai. 2016. Pengantar Industri Pariwisata : Tantangan \& Peluang Bisnis Kreatif. Yogyakarta : Deepublish

Yulianto, Atun. 2017. Analisis Objek Daya Tarik Wisata Favorit Berdasarkan Jumlah Pengunjung Di Daerah Istimewa Wogyakarta. Jurnal Media $\begin{array}{lll}\text { Wisata } & \text { Vol.15 } & \text { NO.2 }\end{array}$ November2017. Yogyakarta:STP AMPTA. 